\title{
PENINGKATAN KETERAMPILAN KEWARGANEGARAAN \\ (CIVIC SKILLS) MELALUI PENERAPAN PEMBELAJARAN KEWARGANEGARAAN BERBASIS PORTOFOLIO
}

\author{
oleh: \\ Mukhamad Murdiono \\ Jurusan PKn dan Hukum, FISE UNY
}

\begin{abstract}
Abstrak
Bergulirnya era reformasi yang dimotori oleh gerakan mahasiswa membawa perubahan hampir di semua aspek kehidupan berbangsa dan bernegara. Pada masa reformasi Pendidikan Kewarganegraan juga sedang dalam proses perubahan menuju Pendidikan Kewarganegaraan dengan paradigma baru (New Indonesian Civic Education). Pendidikan Kewarganegaraan paradigma baru berorientasi pada terbentuknya masyarakat sipil (civil society) dengan memberdayakan warga negara melalui proses pendidikan agar mampu berperan serta secara aktif dalam sistem pemerintahan negara yang demokratis.

Untuk mencapai visi dan misi PKn paradigma baru kemudian dikembangkan tiga kompetensi yang harus dimiliki siswa yang meliputi: pengetahuan kewarganegaraan (civic knowldge), keterampilan kewarganegaraan (civic skills), karakter kewarganegaraan (civic disposition/traits). Keterampilan kewarganegaraan yang akan dikembangkan sangat terkait erat dengan strategi pembelajaran yang digunakan dalam proses pembelajaran kewarganegaraan di sekolah. Salah satu strategi pembelajaran yang dapat meningkatkan keterampilan kewarganegaraan (civic skills) adalah strategi pembelajaran PKn berbasis portofolio.

Strategi pembelajaran berbasis portofolio diyakini sebagai salah satu strategi pembelajaran yang dapat melatih siswa atau mahasiswa berperan serta secara aktif dalam sistem pemerintahan. Melalui penerapan strategi pembelajaran berbasis portofolio peserta didik dilatih untuk turut serta dalam mempengaruhi kebijakan publik yang akan dibuat oleh pemerintah. Strategi ini memungkinkan peserta didik, baik siswa maupun mahasiswa, berlatih memadukan antara konsep yang diperoleh dari buku atau penjelasan guru dengan penerapannya dalam kehidupan sehari-hari. Keterampilan kewarganegaraan yang diperoleh peserta didik dapat tercermin dari prosedur pengembangan portofolio yang meliputi identifikasi masalah, identifikasi alternatif pemecahan masalah, pemilihan alternatif, penentuan rencana tindakan (action plan), pengembangan portofolio, menyajikan portofolio, dan merefleksikan pengalaman belajar.
\end{abstract}

Kata Kunci: PKn paradigma baru, keterampilan kewarganegaraan, strategi pembelajaran berbasis portofolio. 


\section{Pendahuluan}

Pendidikan kewarganegaraan selama ini dianggap sebagai mata pelajaran yang lebih bersifat politis daripada akademis, lemah landasan keilmuannya, dan tidak tampak sosok keilmiahannya. Hal ini menjadikan mata pelajaran PKn kurang menantang dan kurang dimanati oleh siswa atau mahasiswa. Anggapan semacam ini memang ada benarnya, kalau dirunut dari sejarah perkembangan mata pelajaran PKn baik di tingkat sekolah dasar, menengah (SMP/SMA) ataupun di perguruan tinggi. Unsur politis dalam pengembangan materi Pendidikan Kewarganegaraan sangat kentara sekali pada masa berkuasanya rezim Orde Baru.

Paradigma pendidikan yang dianut pada masa Orde Baru lebih mengedepankan pendidikan untuk kepentingan pembangunan. Pendidikan dijadikan sebagai salah salah satu instrumen penting dalam mewujudkan pembangunan. Melalui jargonnya yang sangat terkenal "Pembangunan Manusia Indonesia Seutuhnya", rezim Orde Baru dalam kebijakan-kebijakan pemerintahan yang dijalankan ternyata lebih berorientasi pada pertumbuhan ekonomi semata. Sementara aspek-aspek yang lain kurang mendapatkan perhatian yang lebih serius. Ironisnya pembangunan yang telah dilaksanakan Orde Baru lebih dari 30 tahun, ternyata justru menghasilkan keterpurukan di berbagai bidang dan menimbulkan krisis multidimensi. Pengalaman pada masa Orde Baru itu menjadi pelajaran berharga tentang betapa rapuhnya suatu pembangunan yang hanya menekankan pada aspek materiil dan kepentingan-kepentingan ekonomi belaka.

Bergulirnya era reformasi yang dimotori oleh gerakan mahasiswa membawa perubahan hampir di semua aspek kehidupan berbangsa dan bernegara. 
Pada masa reformasi Pendidikan Kewarganegraan juga sedang dalam proses perubahan menuju Pendidikan Kewarganegaraan dengan paradigma baru (New Indonesian Civic Education). Reformasi itu mulai dari aspek yang mendasar; yaitu reorientasi visi dan misi, revitalisasi fungsi atau peranan, hingga restrukturisasi isi kurikulum dan materi pembelajaran. Seiring dengan itu, dalam sistem pendidikan nasional juga dilakukan pembaharuan kurikulum dengan konsep Kurikulum Berbasis Kompetensi (Competence Based Curriculum) yang kemudian disempurnakan menjadi Kurikulum Tingkat Satuan Pendidikan (KTSP). Penerapan konsep baru ini merupakan salah satu bentuk dan komitmen bersama dalam melakukan reformasi di bidang pendidikan.

Pendidikan Kewarganegaraan paradigma baru berorientasi pada terbentuknya masyarakat sipil (civil society) dengan memberdayakan warga negara melalui proses pendidikan agar mampu berperan serta secara aktif dalam sistem pemerintahan negara yang demokratis. Sejalan dengan visi Pendidikan Kewarganegaraan paradigma baru, misi mata pelajaran ini adalah meningkatkan kompetensi siswa agar mampu menjadi warga negara yang berperan serta secara aktif dalam sistem pemerintahan negara yang demokratis. Untuk mencapai hal itu maka dikembangkan tiga kompetensi yang harus dimiliki siswa yang meliputi: pengetahuan kewarganegaraan (civic knowledge), keterampilan kewarganegaraan (civic skills), karakter kewarganegaraan (civic disposition/traits).

Salah satu aspek penting dalam pengembangan Pendidikan Kewarganegaraan pardigma baru adalah peningkatan keterampilan kewarganegaraan (civic skills). Keterampilan kewarganegaraan yang akan 
dikembangkan, terutama penerapannya dalam mata pelajaran Pendidikan Kewarganegaraan, sangat terkait erat dengan strategi pembelajaran yang digunakan dalam proses pembelajaran kewarganegaraan. Salah satu strategi pembelajaran yang dapat meningkatkan keterampilan kewarganegaraan (civic skills) adalah strategi pembelajaran PKn berbasis portofolio. Strategi pembelajaran berbasis portofolio diyakini sebagai salah satu strategi pembelajaran yang dapat melatih siswa atau mahasiswa berperan serta secara aktif dalam sistem pemerintahan. Melalui penerapan strategi pembelajaran berbasis portofolio peserta didik dilatih untuk turut serta dalam mempengaruhi kebijakan publik yang akan dibuat oleh pemerintah.

\section{Perkembangan Pendidikan Kewarganegaraan}

Nuansa politis dalam pengembangan materi pembelajaran PKn dapat dirunut dari sejarah perkembangan PKn, terutama PKn persekolahan (SMP/SMA). Mata pelajaran ini muncul pertama kali pda tahun 1957 dengan nama Kewarganegaraan, yang isinya sebatas tentang hak dan kewajiban warga negara serta cara-cara memperoleh dan kehilangan (status) kewarganegaraan. Sebagai tindak lanjut dari Dekrit Presiden 5 Juli 1959, Menteri P dan K mengeluarkan Surat Keputusan No. 122274/S tanggal 10 Desember 1959 tentang pembentukan panitia penyusunan buku pedoman mengenai kewajiban-kewajiban dan hak-hak warga negara Indonesia dan hal-hal yang menginsyafkan warga negara tentang sebab-sebab sejarah dan tujuan revolusi Indonesia. Panitia tersebut berhasil menyusun buku "Manusia dan Masyarakat Baru Indonesia" pada tahun 1962 yang menjadi acuan mata pelajaran Civics yang telah muncul pada tahun 
1961. Buku tersebut berisi tentang Sejarah Pergerakan Rakyat Indonesia; Pancasila; UUD 1945; Demokrasi dan Ekonomi Terpimpin; Konperensi AsiaAfrika; Hak dan Kewajiban Warga Negara; Manifesto Politik; Laksana Malaikat dan Lampiran-lampiran Dekrit Presiden, Pidato Lahirnya Pancasila, Panca Wardana, dan Declaration of Human Rigths, serta pidato-pidato Presiden lainnya yang dipaketkan dalam Tujuh Bahan Pokok Indoktrinasi (Tubapi) (Muchson, 2004: 30).

Berakhirnya masa pemerintahan Orde Lama, mengakhiri pula isi mata pelajaran Civics. Artinya, sejak berkuasanya rezim Orde Baru menggantikan Orde Lama hampir seluruh isi mata pelajaran Civics dibuang karena dianggap sudah tidak sesuai dan tidak relevan lagi dengan tuntutan zaman yang terus berkembang. Pada kurikulum 1968 mata pelajaran ini muncul dengan nama Kewargaan Negara, yang isinya di samping Pancasila dan UUD 1945, memuat pula tentang Ketetapan-Ketetapan MPRS 1966, 1967, dan 1968, termasuk GBHN-nya, HAM, serta beberapa materi yang beraspek sejarah, geografi, dan ekonomi.

Sesuai dengan amanat Ketetapan MPR No. IV/MPR/1973, mata pelajaran ini berubah nama menjadi Pendidikan Moral Pancasila (PMP) pada kurikulum 1975. Dengan ditetapkannya Ketetapan MPR No. II/MPR/1978 tentang Pedoman Penghayatan dan Pengamalan Pancasila (P-4), maka terjadilah perkembangan yang cukup substantif mengenai materi mata pelajaran ini, yakni sangat dominannya materi P-4 dalam PMP. Bahkan dalam penjelasan ringkas tentang PMP oleh Depdikbud (1982) dinyatakan bahwa hakikat PMP tidak lain adalah pelaksanaan P-4 melalui jalur pendidikan formal. Sidang MPR tahun 1983 
berhasil menetapkan GBHN baru yang di dalamnya menginstruksikan bahwa Pendidikan Pancasila di dalamnya termasuk materi PMP, pendidikan pelaksanaan P4, dan Pendidikan Sejarah Perjuangan Bangsa (PSPB). Kurikulum 1984 tetap mempertahankan PMP dengan sedikit perubahan rumusan tujuan dan pokok bahasan (Soenarjati dan Cholisin, 1989: 7).

Dominanya materi P-4 dalam mata pelajaran ini tetap berlangsung hingga berlakunya kurikulum 1984 maupun kurikulum 1994, dimana PMP telah berubah nama menjadi PPKn. Dalam perkembangan selanjutnya, materi P-4 secara resmi tidak dipakai lagi dalam kurikulum suplemen 1999. Hal itu ditandai dengan dicabutnya Ketetapan MPR No. II/MPR/1978 yang mengatur tentang P-4 melalui Ketetapan MPR No. XVIII/MPR/1998. Hilangnya materi P-4 dalam mata pelajaran ini menunjukkan bahwa telah terjadi perubahan di bidang pendidikan yang merupakan salah satu wujud dari tunutan reformasi di bidang pendidikan. Bergulirnya reformasi membawa PKn menuju ke arah paradigma baru (New Indonesian Civic Education) yang mengembangkan tiga kompetensi yang meliputi: pengetahuan kewarganegaraan (civic knowledge), keterampilan kewarganegaraan (civic skills), karakter kewarganegaraan (civic disposition/traits).

\section{Pendidikan Kewarganegaraan Paradigma Baru}

Proses reformasi yang mulai bergulir sejak pertengan tahun 1998 merupakan salah satu upaya penataan kembali terhadap kehidupan berbangsa dan bernegara menuju kehidupan yang lebih baik dibandingkan dengan masa-masa sebelumnya. Jika dalam perjalanannya kurang lebih sembilan tahun ini reformasi 
belum menunjukkan perubahan atau perbaikan yang berarti, hal itu disebabkan oleh berbagai faktor. Pertama, aspek-aspek kehidupan yang perlu ditata sedemikian luas, menyeluruh atau total. Reformasi yang "kaffah" berarti penataan dan perbaikan dalam segala aspek kehidupan berbangsa dan bernegara, baik kehidupan ekonomi, politik, sosial-budaya, hankam, pendidikan, dan bidangbidang yang lain. Kedua, kondisi warga negara itu sendiri kurang siap melaksanakan reformasi. Kekurangsiapan itu bukan semata-mata disebabkan perubahan peran yang mendadak, dari kebiasaan sebagai "objek" kemudian menjadi "subjek" dalam kehidupan bernegara, akan tetapi lebih disebabkan oleh kemampuan warga negara yang pada umumnya kurang memadai. Oleh karena itu hal yang esensial dalam reformasi adalah pemberdayaan warga negara yang hakikatnya hampir identik dengan demokratisasi (Muchson, 2004: 31).

Reformasi di bidang pendidikan, khususnya Pendidikan Kewarganegaraan, menyangkut hal-hal yang sifatnya mendasar seperti reorientasi visi dan misi, revitalisasi fungsi atau peranan, hingga restrukturisasi isi kurikulum dan materi pembelajaran. Reorientasi terhadap visi dan misi PKn misalnya dengan jalan melakukan pembaharuan terhadap fungsi PKn, yakni PKn berfungsi sebagai wahana untuk membentuk warga negara yang cerdas, terampil, dan berkarakter yang setia kepada bangsa dan negara Indonesia dengan merefleksikan dirinya dalam kebiasaan berpikir dan bertindak sesuai dengan amanat Pancasila dan UUD 1945.

Secara konseptual dan teoretik sebenarnya PKn telah membekali peserta didik dengan kemampuan untuk berpikir secara kreatif, dan bukan hanya 
memberikan kemampuan kepada peserta didik untuk menghapal materi pelajaran. PKn mengharuskan kepada para peserta didik untuk memiliki tiga kompetensi; yakni pengetahuan kewarganegaraan, keterampilan kewarganegaraan, dan karakter kewarganegaraan, yang kemudian dikenal dengan konsep paradigma baru PKn. Ketiga komponen pokok itu dikembangkan dalam PKn yang bermutu, seperti yang diajukan oleh Center for Civic Education pada tahun 1994 dalam National Standards for Civics and Government. Komponen-komponen tersebut meliputi: civic knowledge, civic skills, dan civic dispositions (Branson, 1999: 825).

Paradigma baru PKn dapat diartikan sebagai cara berpikir baru tentang PKn. Paradigma baru PKn antara lain bercirikan memiliki struktur keilmuan yang jelas, yakni berbasis pada ilmu politik, hukum, dan filsafat moral/Pancasila serta memiliki visi yang kuat untuk nation and character building, pemberdayaan warga negara (citizen empowerment) yang mampu untuk mengembangkan masyarakat kewargaan (civil society). Paradigma baru ini merupakan upaya untuk menggantikan paradigma lama PKn, yaitu antara lain bercirikan struktur keilmuan yang tidak jelas, materi disesuaikan dengan kepentingan politik rezim (hegemoni penguasa), memiliki visi untuk memperkuat state building (negara otoriter birokratis, kooptasi negara), yang bermuara pada posisi warga negara sekedar sebagai kaula/obyek yang sangat lemah ketika berhadapan dengan penguasa. Akibatnya semakin sulit untuk mengembangkan karakter warga negara yang demokratis, sehingga menjadi lahan subur bagi berkembangnya otoriterisme (Cholisin, 2003: 1). 
PKn paradigma baru ini sering disebut sebagai PKn yang bermutu. PKn yang bermutu inilah sesungguhnya merupakan jati diri PKn. PKn yang bermutu ini juga sesungguhnya telah mengandung di dalamnya pemenuhan tuntutantuntutan dalam kurikulum PKn terbaru (KTSP). Fungsi dan tujuan kewarganegaraan yang ada dalam kurikulum tersebut sebenarnya terdapat tiga komponen penting yang hendak dikembangkan, yaitu: warga negara yang cerdas (civic knowledge), warga negara yang terampil (civic skills), dan warga negara yang berkarakter (civic disposition/traits).

Dimensi pengetahuan kewarganegaraan (civic knowledge) mencakup bidang politik, hukum, dan moral. Secara lebih terperinci, materi pengetahuan kewarganegaraan meliputi pengetahuan tentang prinsip-prinsip dan proses demokrasi, lembaga pemerintah dan non pemerintah, identitas nasional, pemerintah berdasar hukum (rule of law) dan peradilan bebas yang tidak memihak, konstitusi, sejarah nasional, hak dan tanggungjawab warganegara, hak asasi manusia, hak sipil, dan hak politik (Depdiknas, 2002:10).

Dimensi keterampilan kewarganegaraan (civic skills) meliputi keterampilan partisipasi dalam kehidupan berbangsa dan bernegara, misalnya: berperan serta aktif mewujudkan masyarakat madani, keterampilan mempengaruhi dan monitoring jalannya pemerintahan dan proses pengambilan keputusan politik, keterampilan memecahkan masalah-masalah sosial keterampilan mengadakan koalisi, kerjasama, dan mengelola konflik. Sedangkan dimensi nilai-nilai kewarganegaraan (civic values) mencakup percaya diri, komitmen, penguasaan atas nilai religius, norma dan moral luhur, nilai keadilan, 
demokratis, toleransi, kebebasan individual, kebebasan berbicara, kebebasan pers, kebebasan berserikat dan berkumpul, dan perlindungan terhadap minoritas (Depdiknas, 2002: 11).

\section{Pembelajaran PKn dengan Strategi Pembelajaran Portofolio}

Pendidikan kewarganegaraan sebagai bagian dari IPS (social studies) memiliki tujuan yang berdekatan. Menurut The National Council for the Social Studies (Sunal, 1993: 5) tujuan social studies adalah "the purpose of social studies is to prepare young people to be humane, rational, participating citizens in a world that is becoming increasingly interdependent”. Tujuan ini merupakan sudut pandang yang paling dominan dalam social studies. Sedangkan Jarolimek (1986:4) menyatakan misi utama social studies sebagai berikut:

The major mission of social studies education is to help children learn about the social world in which they live and how it got that way; to learn to cope with social realities; and to develop the knowledge, attitudes, and skills needed to help shape an enlightened humanity.

Tujuan dan misi social studies tersebut juga merupakan tujuan dari PKn, yaitu membentuk warganegara yang baik (good citizens). Chapin (1989: 126) menyatakan bahwa "good citizens in our local communities are those who perform acts of conserving public property, coming to the aid of someone in distress, and so on". Lebih lanjut Chapin menyatakan bahwa pendidikan kewarganegaraan bertujuan menyiapkan peserta didik untuk menjadi warganegara yang partisipatorik, memahami tentang sistem pemerintahan dan cara kerjanya, peran warganegara, memahami hak dan kewajiban, dan membiasakan untuk membuat pilihan dan keputusan dengan pertimbangan yang baik. 
Menurut Martorella (1994: 8) warga negara yang baik sebagai tujuan dari PKn adalah warganegara yang efektif (effective citizen), yaitu warga negara bersifat reflektif, cakap, dan memiliki kepedulian. Lebih lanjut Martorella (1994:10) menggambarkan warganegara yang efektif sebagai berikut:

Reflective individuals are critical thinkers who make decisions and solve problems on the basis of the best evidence available. Competent citizens posses a repertoire of skills to aid them in decision making and problem solving. Concerned citizens investigate their social world, address issues they identify as significant, exercise their rights, and carry out their responsibilities as members of a social community.

PKn bukan semata-mata hanya mengajarkan pasal-pasal Undang-Undang Dasar (UUD). Tapi lebih jauh PKn mengkaji perilaku warga negara dalam hubungannya dengan warga negara lain dan alam sekitarnya. Objek studi PKn adalah warga negara dalam hubungannya dengan organisasi kemasyarakatan, sosial, ekonomi, agama, kebudayaan dan negara. Menurut M. Numan Somantri (2001: 276) termasuk dalam objek studi Civics ialah: tingkah laku, tipe pertumbuhan pikir, potensi yang ada dalam setiap diri warga negara, hak dan kewajiban, cita-cita dan aspirasi, kesadaran (patriotisme, nasionalisme, pengertian internasional, moral Pancasila), usaha atau kegiatan dan partisipasi serta tanggungjawab.

Strategi pembelajaran yang tepat untuk mencapai tujuan tersebut adalah strategi yang bersifat dialogis-kritis, pengalaman langsung (direct experiences), kolaboratif, dan kooperatif. Strategi pembelajaran seperti ini menekanakan pada tiga ranah pembelajaran, yaitu: kognitif, afektif, dan psikomotorik. Hal ini sejalan dengan apa yang dinyatakan Kirschenbaum (1995: 24-26) bahwa aspek citizenship education meliputi: knowledge, appreciation, critical thinking skills, 
communication skills, cooperation skills, and conflict resolution skills. Aspekaspek tersebut lebih lanjut dinyatakan Kirschenbaum dalam pelaksanaannya diperlukan pendekatan secara komprehensif yang meliputi inkulkasi (inculcaty), pemodelan (modeling), fasilitasi (facilitaty), dan pengembangan keterampilan (skills development).

Salah satu strategi pembelajaran yang tepat digunakan untuk meningkatkan keterampilan kewarganegaraan (civic skills) adalah strategi pembelajaran kewarganegaraan berbasis portofolio. Istilah portofolio ini pada awalnya digunakan untuk bidang seni, yaitu biasa diartikan sebagai kumpulan yang mewakili sebuah karya. Biasanya para seniman seringkali mengumpulkan karya-karya seni mereka untuk tujuan tertentu, seperti pameran karya seni yang berpindah-pindah tempat. Secara periodik para seniman akan memamerkan karya seni yang telah terkumpul, dan biasanya karya yang ditampilkan merupakan karya yang terbaik.

Dalam perkembangan selanjutnya istilah portofolio juga diterapkan dalam dunia pendidikan. Portofolio dalam dunia pendidikan berisi hasil pekerjaan terpilih (terbaik) peserta didik yang menunjukkan perubahan perkembangan dalam belajar. The Northwest Evaluation Association (Barret, 2001: 1) memberikan definisi portofolio sebagai berikut:

A portfolio is a purposeful collection of student work that exhibits the student's efforts, progress and achievements in one or more areas. The collection must include student participation in selecting contens, the criteria for selection; the criteria for judging merit, and evidence of student self-reflection. 
Portofolio dapat pula diartikan sebagai suatu wujud benda fisik, sebagai suatu proses sosial pedagogis, maupun sebagai adjective. Sebagai suatu benda fisik portofolio itu adalah bundel, yakni kumpulan atau dokumentasi hasil pekerjaan peserta didik yang disimpan pada suatu bundel. Misalnya hasil tes awal (pretest), tugas-tugas, catatan anekdot, piagam penghargaan, keterangan melaksanakan tugas terstruktur, hasil tes akhir (posttest), dan sebagainya. Sebagai suatu proses sosial pedagogis, portofolio adalah kumpulan pengalaman belajar yang terdapat di dalam pikiran peserta didik baik yang berwujud pengetahuan (kognitif), keterampilan (skill), maupun nilai dan sikap (afektif). Adapun sebagai suatu adjective portofolio sering kali disandingkan dengan konsep lain, misalnya dengan konsep pembelajaran dan penilaian. Jika disandingkan dengan konsep pembelajaran maka dikenal istilah pembelajaran berbasis portofolio (portfolio based learning), sedangkan jika disandingkan dengan konsep penilaian maka dikenal istilah penilaian berbasis portofolio (portfolio based assessment) (Dasim Budimansyah, 2002: 1-2).

Dasar dari strategi pembelajaran portofolio adalah teori belajar konstruktivisme, yang pada prinsipnya menggambarkan bahwa pembelajar membentuk atau membangun pengetahuannya melalui interaksi dengan lingkungannya. Prinsip yang paling umum dan paling esensial yang dapat diturunkan dari konstruktivisme, bahwa dalam merancang suatu pembelajaran peserta didik memperoleh banyak pengetahuan di luar sekolah. Pemberian pengalaman belajar yang beragam memberikan kesempatan untuk mengelaborasikannya. Dengan demikian pendidikan -dalam hal ini pembelajaran 
-hendaknya memperhatikan hal di atas dan menunjang proses alamiah ini (Arnie Fajar, 2004: 44).

Penerapan konstruktivisme dalam pembelajaran, berarti menempatkan peserta didik pada posisi sentral dalam keseluruhan program pembelajaran. Sebagai contoh isu atau masalah yang muncul digunakan sebagai dasar pembahasan, diskusi, dan investigasi kegiatan di dalam atau di luar kelas. Pembelajaran berbasis portofolio sangat memperhatikan dan bahkan melakukan hal tersebut dalam proses kegiatan belajar.

Portofolio dalam pembelajaran dapat dilihat dari tiga aspek, yaitu: dari segi strategi/metode, media, dan evaluasi. Dari segi strategi/metode, pembelajaran portofolio merupakan penerapan strategi pemecahan masalah. Ditinjau dari segi media, pembelajaran portofolio menyangkut pengembangan dan produksi media. Selanjutnya ditinjau dari segi evaluasi, pembelajaran portofolio merupakan penerapan teknik evaluasi yang unik (Abdul Gafur, 2003: 3).

Melalui pembelajaran portofolio, di samping memperoleh pengalaman fisik terhadap objek dalam pembelajaran, mahasiswa juga memperoleh pengalaman atau terlibat secara mental. Pengalaman fisik dalam arti melibatkan mahasiswa atau mempertemukan mahasiswa dengan objek pembelajaran. Pengalaman mental dalam arti memperhatikan informasi awal yang telah ada pada diri mahasiswa, dan memberikan kebebasan kepada mahasiswa untuk menyusun (merekonstruksi) sendiri-sendiri informasi yang diperolehnya.

Strategi pembelajaran berbasis portofolio memberi keragaman sumber belajar, dan memberikan keleluasaan kepada mahasiswa untuk memilih sumber 
belajar yang sesuai sebagai landasan untuk menyusun fenomena alam/masyarakat pada masing-masing mahasiswa. Hal ini sesuai dengan salah satu prinsip dalam pengembangan kurikulum berbasis kompetensi, yakni berpusat pada peserta didik sebagai pembangun pengetahuan. Artinya upaya untuk memandirikan peserta didik untuk belajar, berkolaborasi, membantu teman, mengadakan pengamatan, dan penilaian diri untuk suatu refleksi akan mendorong mereka membangun pengetahuannya sendiri. Dengan demikian baru akan diperoleh melalui pengalaman langsung secara lebih efektif. Dalam hal ini peran dosen adalah sebagai fasilitator.

Keterampilan kewarganegaraan yang didapatkan dengan menerapkan strategi pembelajaran portofolio adalah keterampilan berpartisipasi (participation skills) dan keterampilan intelektual (intelectual skills). Pentingnya keterampilan berpartisipasi dalam demokrasi digambarkan oleh Aristoteles dalam bukunya Politics (340M) (dalam Branson,1999: 4). Aristoteles menuliskan: "Jika kebebasan dan kesamaan -sebagaimana menurut pendapat sebagian orang -dapat diperoleh terutama dalam demokrasi, maka kebebasan dan kesamaan itu akan dapat dicapai apabila semua orang tanpa kecuali ikut ambil bagian sepenuhnya dalam pemerintahan". Keterampilan berpartisipasi tersebut bisa dalam bentuk berinteraksi terhadap obyek yang berkaitan dengan masalah-masalah publik, memantau atau memonitor masalah politik dan pemerintahan, mempengaruhi proses politik baik secara formal ataupun informal (Cholisin, 2004: 19-20).

Keterampilan kewarganegaraan lain yang didapatkan dengan menerapkan pembelajaran berbasis portofolio adalah keterampilan intelektual (intelectual 
skills). Keterampilan intelektual ini meliputi: keterampilan mengidentifikasi, menggambarkan atau memberikan ilustrasi, menjelaskan atau mengklarifikasi, menganalisis, mengevaluasi, mengambil pendapat atau posisi, dan mempertahankan pendapat atau posisi. Keterampilan-keterampilan ini bisa didapatkan oleh peserta didik selama proses pembelajaran berlangsung. Dengan menerapkan strategi pembelajaran portofolio sebenarnya siswa atau mahasiswa juga melatih keterampilan-keterampilan tersebut. Hal itu dapat dilihat dari langkah-langkah yang dilaksanakan dalam mengembangkan portofolio yang meliputi: identifikasi masalah, identifikasi alternatif pemecahan masalah, pemilihan alternatif, penentuan rencana tindakan (action plan), pengembangan portofolio, menyajikan portofolio, merefleksikan pengalaman belajar (CCE Indonesia, 2003:12-20).

\section{Kesimpulan}

Pendidikan Kewarganegaraan paradigma baru merupakan sebuah agenda besar yang bukan hanya memperbaiki atau menyempurnakan, melainkan membongkar total "sebuah bangunan" mulai dari fundamen seperti visi dan misi sampai pada struktur dan konstruksinya. Paradigma baru tersebut mengembangkan tiga kompetensi kewarganegaraan yang meliputi: civic knowledge (pengetahuan kewarganegaraan), civic skills (kecakapan/keterampilan kewarganegaraan), dan civic disposition/traits (watak/perilaku kewarganegaraan). Keterampilan kewarganegaraan (civic skills) merupakan keterampilan yang dikembangkan dari pengetahuan kewarganegaraan (civic knowledge) agar pengetahuan yang diperoleh warga negara menjadi sesuatu yang bermakna dan 
dapat dimanfaatkan dalam menghadapi masalah-masalah kehidupan berbangsa dan bernegara. Civic skills mencakup intelectual skills (keterampilan intelektual) dan participation skills (keterampilan partisipasi).

Keterampilan intelektual (intelectual skills) sebagai bagian dari keterampilan kewarganegaraan sangat penting untuk dimiliki oleh warga negara Indonesia agar menjadi warga negara yang berwawasan luas, efektif dan bertanggungjawab. Keterampilan intelektual dalam prakteknya diwujudkan melalui keterampilan berpikir kritis yang meliputi: mengidentifikasi, menggambarkan atau mendeskripsikan, menjelaskan, menganalisis, mengevaluasi, menentukan dan mempertahankan pendapat yang berkenaan dengan masalahmasalah publik. Sementara keterampilan partisipasi (participation skills) meliputi: berinterkasi, memantau atau memonitor, dan mempengaruhi proses politik.

Keterampilan-keterampilan kewarganegaraan tersebut dalam proses pembelajaran PKn menuntut adanya penerapan strategi pembelajaran yang tepat. Pemilihan strategi pembelajaran yang tepat merupakan salah satu faktor penting yang dapat menetukan keberhasilan proses belajar mengajar. Salah satu strategi pembelajaran yang tepat untuk meningkatkan keterampilan-keterampilan kewarganegaraan seperti yang telah disebutkan di muka adalah strategi pembelajaran kewarganegaraan berbasis portofolio. Strategi ini memungkinkan peserta didik, baik siswa maupun mahasiswa, berlatih memadukan antara konsep yang diperoleh dari buku atau penjelasan guru dengan penerapannya dalam kehidupan sehari-hari. Keterampilan kewarganegaraan yang diperoleh peserta didik dapat tercermin dari prosedur pengembangan portofolio yang meliputi 
identifikasi masalah, identifikasi alternatif pemecahan masalah, pemilihan alternatif, penentuan rencana tindakan (action plan), pengembangan portofolio, menyajikan portofolio, dan merefleksikan pengalaman belajar.

\section{DAFTAR PUSTAKA}

Abdul Gafur. (2003). Evaluasi Implementasi hasil penataran pembelajaran portofolio kewarganegaraan (civic) guru PPKn SLTP di Propinsi DIY. Hasil Penelitian tidak Dipublikasikan, UNY.

Arnie Fajar. (2003). Portofolio Dalam Pembelajaran IPS. Bandung: Remaja Rosda Karya.

Barret, H.C. (2001). Eletronic Portfolios. Diakses 22 Desember 2005 dari http://www.electronicportfolios.org/portfolios/encyclopediaentry.html.

Branson, M. S. (Eds.). (1999). Belajar Civic Education dari Amerika. (Terjemahan Syafruddin, dkk.) Yogyakarta: Lembaga Kajian Islam dan Sosial (LKIS) dan The Asia Foundation (TAF).

Center for Civic Education. (2003). Kami Bangsa Indonesia: Buku Panduan Guru. Jakarta: CCE Indonesia.

Chapin, J. R. dan Rosemary G. M. (1989). Elementary Social Studies: A Practical Guide, Second Edition. New York: Longman.

Cholisin. (Oktober 2003). PPKn Paradigma Baru dan Pengembangannya dalam $K B K$. Makalah Disampaikan pada Training of Trainer (ToT) Guru SLTP Mata Pelajaran PPKn, di Surakarta.

.(2004). "Konsolidasi Demokrasi Melalui Pengembangan Karakter Kewarganegaraan". Jurnal Civics: Media Kajian Kewarganegaraan, Vol. 1 Nomor 1. Yogyakarta: Jurusan PPKn, FIS UNY.

Dasim Budimansyah. (2002). Model Pembelajaran dan Penilaian Berbasis Portofolio. Bandung: Genesindo.

Departemen Pendidikan Nasional. (2002). Standar Operasional Prosedur (SOP) Pengembangan Silabus Berbasis Kemampuan Dasar Siswa Sekolah Menengah Umum (SMU) Mata Pelajaran Kewarganegaraan. Jakarta: Ditdikmenum Ditjen Dikdasmen Depdiknas RI. 
Jarolimek, J. (1986). Social Studies in Elementary Education, $\left(7^{\text {th }}\right.$ ed.). New York: Macmillan Pubishing Company.

Kirschenbaum, H. (1995). 100 Ways to Enhance Values and Morality in Schools and Youth Settings. Massachusetts: Allyn \& Bacon.

Martorella, P. H. (1994). Social Studies for Elementary School Children: Developing Young Citizens. New York: Macmillan College Publishing Company, Inc.

Muchson Abdurrahman. (2004). "Pendidikan Kewarganegaraan Paradigma Baru dan Impelementasinya dalam Kurikulum Berbasis Kompetensi”. Jurnal Civic: Media Kajian Kewarganegaraan, Vol. 1 Nomor 1. Yogyakarta: Jurusan Pendidikan Pancasila dan Kewarganegaraan, FIS UNY.

Muhammad Numan Somantri. (2001). Menggagas Pembaharuan IPS. Bandung: Remaja Rosda Karya.

Soenarjati Muhajir dan Cholisin. (1989). Dasar dan Konsep Pendidikan Pancasila. Yogyakarta: Laboratorium Jurusan PMP dan KN.

Sunal, C. S. dan Mary E. H. (1993). Social Studies: and The Elementary/Middle School Student. Orlando: Harcourt Brace College Publishers. 
Tentang Penulis :

Mukhamad Murdiono, lahir di Tonjong, Brebes, 30 Juni 1979. Lulus Sarjana Pendidikan Pancasila dan Kewarganegaraan (PPKn) FIS UNY tahun 2003, dengan predikat Cumlaude. Tahun 2004 diterima sebagai staf pengajar di Jurusan PKn dan Hukum FISE UNY. Pada tahun yang sama melanjutkan studi magister pada program studi Pendidikan IPS Pascasarjana UNY dan lulus tahun 2006. Finalis Lomba Karya Tulis Ilmiah Bidang Pemerintahan se-Indonesia di STPDN, Jatinangor (tahun 2002) dengan judul Karya Tulis : "Studi Deskriptif Model Birokrasi Pemerintah Era Otonomi Daerah di Kabupaten Brebes". Penelitian relevan yang pernah dilakukan 2 tahun terakhir: "Analisis Kritis Terhadap Pemikiran Politik Ibnu Khaldun Tentang Citra Penguasa Ideal" (Penelitian FISE UNY, 2004), "Peran Partai Politik dalam Pendidikan Pemilih Pada Pemilihan Umum 2004 di Kabupaten Sleman, Daerah Istimewa Yogyakarta" (Penelitian Dosen Muda, Dikti Depdiknas, 2005). 